\title{
Distribution and Fractionation of Potentially Toxic Metals under Different Land-Use Patterns in Suburban Areas
}

\author{
Zeyang Zhao ${ }^{1}$, Zhizhong Zhao ${ }^{1 *}$, Bo Fu², Dan Wu${ }^{1}$, Junguang Wang ${ }^{1}$, \\ Yan $\mathrm{Li}^{3}$, Wei Tang ${ }^{1}$ \\ ${ }^{1}$ College of Geography and Environmental Science, Hainan Normal University, Haikou, Hainan, China \\ ${ }^{2}$ Center for Catalysis and Clean Energy, Gold Coast Campus, Griffith University, Queensland, Australia \\ ${ }^{3}$ College of Life Sciences, Hainan Normal University, Haikou, Hainan, China
}

Received: 29 January 2021

Accepted: 23 June 2021

\begin{abstract}
To explore the geochemical effects of land-use patterns on potentially toxic metals in agricultural soils in tropical areas, soil samples were collected in Hainan Island, China. Total concentrations of chromium, copper, lead and zinc were analyzed by inductively coupled plasma mass spectrometry. The sequential extraction procedure was applied to determine the fractions of these potentially toxic metals. The results showed that the concentrations of potentially toxic metals differed among different landuse types. The concentrations of $\mathrm{Cr}, \mathrm{Pb}$ and $\mathrm{Zn}$ revealed the following order: abandoned cropland> paddy field $>$ vegetable land, while $\mathrm{Cu}$ was ordered as abandoned cropland $>$ vegetable land $>$ paddy field. Fractionation analysis showed that the carbonate-bound fraction was present in high proportion in abandoned croplands, the Fe-Mn oxide-bound fraction and the organic matter-bound fraction were present in high proportion in paddy fields, and the exchangeable fraction and residual fraction were present in high proportion in vegetable lands. The chemical fractionations of potentially toxic metals were correlated with $\mathrm{pH}$ and organic matter, resulting in the transformation of different fractions. The results of this study contribute to a better understanding of the effects of land-use patterns on potentially toxic metals in tropical areas.
\end{abstract}

Keywords: chemical fraction, heavy metals, land-use type, soil property, suburban soil

\footnotetext{
*e-mail: hnenvironment@163.com
} 


\section{Introduction}

Soil is an important part of the ecological environment and the material basis for human survival and sustainable development. However, with sewage irrigation and the irrational use of pesticides and fertilizers, the problem of potentially toxic metal pollution in soil has become increasingly serious [1-2]. In addition, potentially toxic metals have limited selfpurification capacity; they do not migrate readily and cannot be degraded by microorganisms [3]. Potentially toxic metals can be enriched in living organisms, e.g., they can enter the human body through water, plants and other media, endangering human health [4-5]. When potentially toxic metals accumulate to a certain extent in the soil, they will also lead to the reduction of soil productivity and crop yield, thus affecting the sustainable development of society and the economy [6]. Since soil properties such as soil $\mathrm{pH}$, Eh and SOM (soil organic matter) content are highly dependent on land use and cropping systems, it is important to assess potentially toxic metal distribution and fractionation under contrasting land type (e.g., paddy land, abandoned land and vegetable land) [7]. The land type can significantly change the properties and conditions of soils and further affect the bioavailability of potentially toxic metals [8]. Through dissolution, adsorption, complexation, precipitation, condensation and other reactions, potentially toxic metals exist in various forms in soil, including the exchangeable fraction, carbonatebound fraction, Fe-Mn oxide-bound fraction, organic matter-bound fraction and residual fraction [9-10]. Even if the total concentration is the same, the biological effects and environmental impacts are different due to the variation in fractionation. By exploring the available potentially toxic metals in soil, which are easily absorbed and utilized by organisms and then transferred through the food chain, the soil pollution status of potentially toxic metals and the harm caused to the environment can be better evaluated [4]. The pollution mechanism of potentially toxic metals in the soil system and organisms can be further understood.

In recent years, the distribution characteristics, influential factors, pollution assessment and remediation techniques of potentially toxic metals in soil under different land-use patterns have been reported by some researchers [11-13]. However, research on certain topics should be further studied, for example, the effect of land-use patterns on the fractionation distribution of potentially toxic metals on a typical tropical region; why the fraction concentrations differ under different land-use patterns; and the influence of the unique tropical climate of Hainan Island on fraction concentrations. For this, the following hypotheses were tested: 1) soil depths and land-use patterns (paddy field $(\mathrm{PF})$, abandoned cropland (AC), vegetable land (VL)) influence the total concentrations of potentially toxic metals ( $\mathrm{Cr}, \mathrm{Cu}, \mathrm{Pb}$ and $\mathrm{Zn}$ ); 2) land-use types influence the chemical fractionation of potentially toxic metals; and 3) soil chemical properties ( $\mathrm{pH}$ and SOM) influence the fractionation of potentially toxic metals. An attempt was made to identify the effects of land-use patterns on selected soil properties and potentially toxic metals in tropical areas.

\section{Materials and Methods}

\section{Study Area}

Dingan County $\left(19^{\circ} 13^{\prime}-19^{\circ} 44^{\prime} \mathrm{N}, 110^{\circ} 07^{\prime}-110^{\circ} 31^{\prime} \mathrm{E}\right)$ is located in northeastern Hainan Island, China. The study area is classified as a tropical monsoon climate zone, with high annual precipitation and frequent typhoons [2]. It has an annual temperature of $24^{\circ} \mathrm{C}$ and an annual average precipitation of $1953 \mathrm{~mm}$, with an uneven temporal distribution and most precipitation falling between May and October [14]. The maximum precipitation in a day is more than $200 \mathrm{~mm}$. The study area is located in the Latosol zone of the monsoon forest in tropical temperate and humid areas. Paddy soil, lateritic soil and tidal sand soil are the main representative soil types.

\section{Sample Sources and Pretreatment}

Based on the understanding of the distribution of agricultural land in the study area, the soil of PF, AC and VL was selected as the research objects according to the principles of typicality and representativeness. The basic situation of each land-use pattern is as follows:

1) PF: Rice has been cultivated for more than 5 years; the planting method is based on crop rotation.

2) AC: Rice, peanuts and other crops were planted before the cropland was abandoned. Weeds and small trees grew on the surface after the cropland was abandoned for 3-5 years, with good coverage.

3) VL: Mainly planted cowpea, peanuts, Pachyrhizus, Luffa and other crops.

Five sampling sites with superior agricultural production conditions, complex land-use patterns and management measures were selected in the research area, as illustrated in Fig. 1. At each sampling site, adjacent PF, AC and VL were selected as sample plots, and there was a sample plot from PF, a sample plot from $\mathrm{AC}$ and a sample plot from VL. A total of 15 sample plots were selected. For each plot, three samples were collected from 0-10, 10-20 and 20-30 cm layer, respectively. A total of 45 samples were collected in the same time during soil sampling ( 5 sampling sites $\times 3$ land-use patterns $\times 3$ depths). A composite soil sample of 10 subsamples was collected within an area of about $50 \mathrm{~m} \times 50 \mathrm{~m}$. A total of $2 \mathrm{~kg}$ of fresh soil was collected from the mixed samples. At the same time, we recorded the cultivation and fertilization situation of the sample land areas in recent years through investigation. 


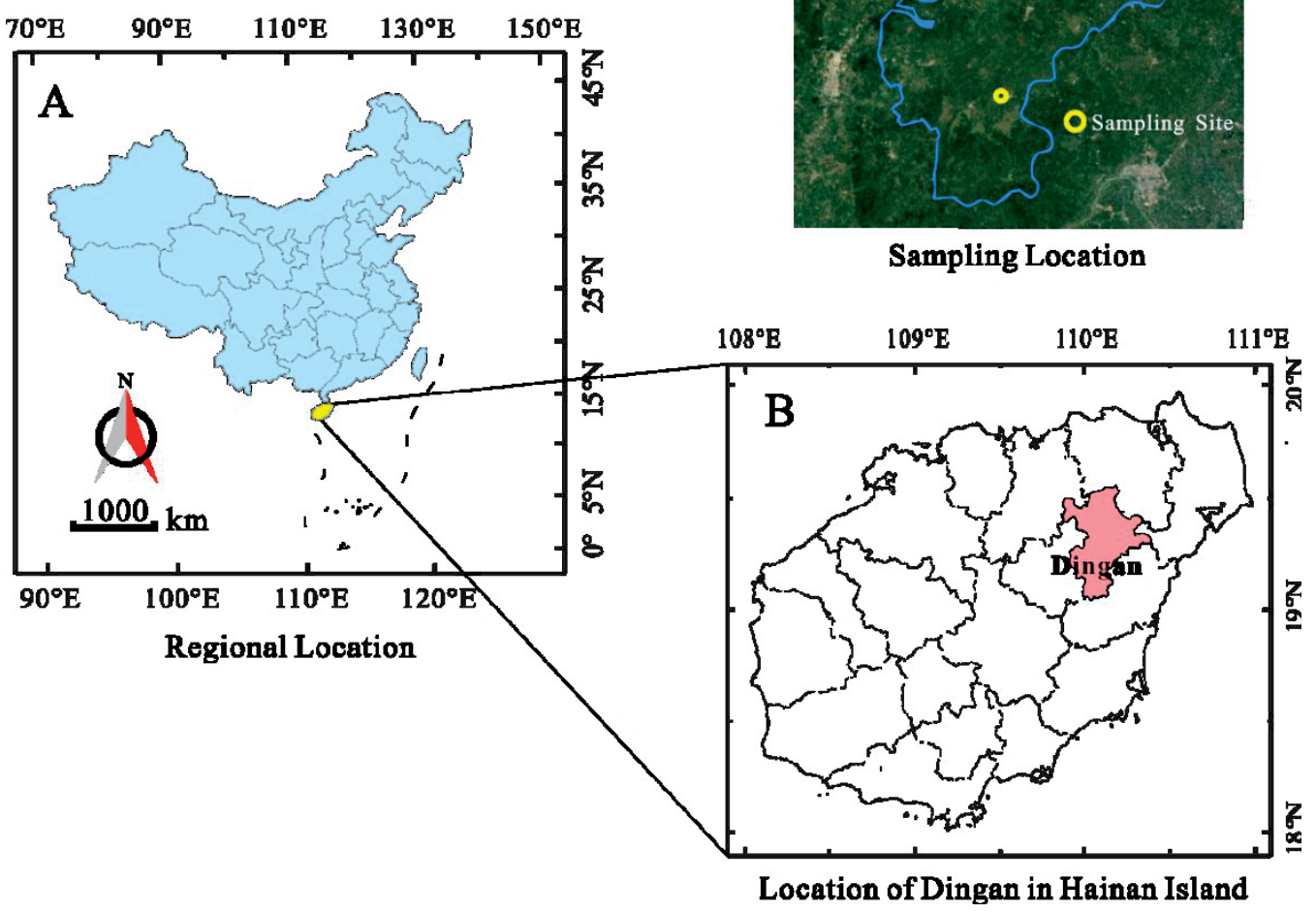

Fig. 1. The location of the study area and distribution of sampling sites.

The collected soil samples were stored in polyethylene bags for transport to the laboratory.

Samples were placed in plastic trays. Impurities such as plant roots and gravel were removed. Then, clods were air-dried $\left(20-25^{\circ} \mathrm{C}\right)$, crushed into small particles with a wooden hammer and sieved through a $0.15-\mathrm{mm}$ nylon sieve. These samples were used for soil $\mathrm{pH}, \mathrm{SOM}$ and elemental analyses.

\section{Analytical Methods}

The soil samples under different land-use patterns were analyzed after acid microwave digestion (ETHOS A, Milestone, Sorisole, BG, Italy). Soil samples (0.1 g dry weight) were digested in a pre-cleaned Teflon digestion tank with a solution of concentrated nitric acid $\left(65 \% \mathrm{HNO}_{3} ; 6 \mathrm{~mL}\right)$ and hydrofluoric acid $(65 \% \mathrm{HF}$; $3 \mathrm{~mL}$ ). The samples were subjected to acid microwave digestion for $20 \mathrm{~min}$ after heating up to $200^{\circ} \mathrm{C}$. After digestion and cooling, the digest solution was placed on a hot plate, heated at $120^{\circ} \mathrm{C}$ to near dryness with $0.5 \mathrm{~mL}$ of $\mathrm{H}_{2} \mathrm{O}_{2}$, and washed and dissolved with $0.02 \mathrm{~mol}$ of $\mathrm{HNO}_{3}$ after cooling. Each sample was quantitatively transferred to a volumetric flask, which was then filled up to $50 \mathrm{~mL}$ with ultrapure water. Guaranteed reagentgrade chemicals and ultra-pure water were used for all

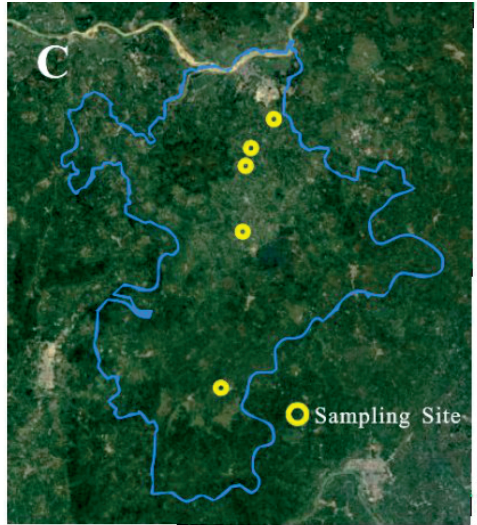

Sampling Location

B

ocation of Dingan in Hainan Island procedures, unless stated otherwise. The concentrations of potentially toxic metals were measured using inductively coupled plasma-mass spectrometry (ICPMS, Agilent 7900, Agilent Technologies, Santa Clara, CA, USA). An environmental mixed calibration standard of $\mathrm{Cr}, \mathrm{Cu}, \mathrm{Pb}$ and $\mathrm{Zn}(10 \mu \mathrm{g} / \mathrm{mL}$, Agilent, Part\#5183-4688) was diluted to produce a standard solution series in stages with 5\% nitric acid (Merck, Germany). A mixed internal standard stock solution of ${ }^{6} \mathrm{Li},{ }^{45} \mathrm{Sc},{ }^{72} \mathrm{Ge},{ }^{89} \mathrm{Y},{ }^{115} \mathrm{In},{ }^{159} \mathrm{~Tb}$, and ${ }^{209} \mathrm{Bi}(10 \mu \mathrm{g} / \mathrm{mL}$, Agilent, part\#5183-4680) was diluted to $1 \mu \mathrm{g} / \mathrm{mL}$ with $5 \%$ nitric acid (Merck, Germany). Under optimum conditions, blank and standard solution series were measured, and the standard curves were automatically drawn by the instrument $(r>0.9999)$. The main operating parameters of the instrument were as follows: RF power $1550 \mathrm{~W}$, cooling gas $15.0 \mathrm{~L} / \mathrm{min}$, auxiliary gas $1.0 \mathrm{~L} / \mathrm{min}$, carrier gas $1.06 \mathrm{~L} / \mathrm{min}$, oxide formation $(\mathrm{CeO} / \mathrm{Ce}<0.5 \%)$, doubly charged $\left(\mathrm{Ce}^{2+} / \mathrm{Ce}^{+}<2 \%\right)$. The isotopes used were ${ }^{53} \mathrm{Cr},{ }^{66} \mathrm{Zn},{ }^{63} \mathrm{Cu}$ and ${ }^{208} \mathrm{~Pb}$. The recoveries were between $85 \%$ and $125 \%$, and the relative standard deviation was less than $5 \%$. Precision and accuracy for potentially toxic metals analysis $(\mathrm{Cr}, \mathrm{Cu}, \mathrm{Pb}$ and $\mathrm{Zn})$ are verified using standard reference materials from the National Research Center for Geo analysis of China [sediment, GBW07407]. 
Table 1. Sequential extraction procedure and the corresponding fractions.

\begin{tabular}{|c|c|c|}
\hline Step & Fraction & Extraction procedure \\
\hline 1 & Exchangeable & $1 \mathrm{~g}$ of soil sample, $8 \mathrm{~mL} 1 \mathrm{~mol} / \mathrm{L} \mathrm{MgCl}_{2}, \mathrm{pH} 7.0$, shake $1 \mathrm{~h}$, room temperature \\
\hline 2 & Carbonate-bound & $8 \mathrm{~mL} 1 \mathrm{~mol} / \mathrm{L} \mathrm{CH}_{3} \mathrm{COONa}$, adjusted $\mathrm{pH}$ to 5.0 with $\mathrm{CH}_{3} \mathrm{COOH}$, shake $5 \mathrm{~h}$, room temperature \\
\hline 3 & Fe-Mn oxide-bound & $20 \mathrm{~mL} 0.04 \mathrm{~mol} / \mathrm{L} \mathrm{NH}_{2} \mathrm{OH} \cdot \mathrm{HCl}$ in $25 \% \mathrm{CH}_{3} \mathrm{COOH}, \mathrm{pH} 2.0$, water bath, $96^{\circ} \mathrm{C}, 6 \mathrm{~h}$, occasional shaking \\
\hline 4 & Organic matter-bound & $\begin{array}{c}3 \mathrm{~mL} 0.02 \mathrm{~mol} / \mathrm{L} \mathrm{HNO}_{3}, 30 \% \mathrm{H}_{2} \mathrm{O}_{2} \text { (adjusted to } \mathrm{pH} 2.0 \text { ), water bath, } 85^{\circ} \mathrm{C}, 5 \mathrm{~h}, 3.2 \mathrm{~mol} / \mathrm{L} \\
\mathrm{CH}_{3} \mathrm{COONH}_{4} \text { in } 20 \%(\mathrm{v} / \mathrm{v}) \mathrm{HNO}_{3} \text {, shake } 30 \mathrm{~min}\end{array}$ \\
\hline 5 & Residual & $3 \mathrm{~mL} \mathrm{HNO}_{3}+\mathrm{HClO}_{4}+\mathrm{HF}$ under high pressure, $170^{\circ} \mathrm{C}$ \\
\hline
\end{tabular}

The potentially toxic metal concentrations of each sample and blank samples were analyzed.

A sequential extraction scheme was applied to determine the fraction of potentially toxic metals in soil samples. The $\mathrm{Cr}, \mathrm{Cu}, \mathrm{Pb}$ and $\mathrm{Zn}$ concentrations of different fractions were determined by the sequential extraction procedure of Tessier et al. [15]. The chemical reagents, extraction conditions and corresponding fractions are listed in Table 1. Accepted recoveries rage from $93 \%$ to $112 \%$. Differences in potentially toxic metal concentrations between the determined and certified values are less than $10 \%$.

Soil $\mathrm{pH}$ was determined in a 1:5 (soil: water ratio, $\mathrm{w} / \mathrm{v})$ suspension with a $\mathrm{pH}$ meter [16]. Soil organic carbon was first measured by wet oxidation, and then was calculated as SOM using the transfer factor 1.724 [17].

The significant differences of potentially toxic metal distributions were determined by one-way analysis of variance (ANOVA), followed by Duncan's multiple comparisons [18]. Correlations between fraction concentrations of potentially toxic metals and selected soil properties were tested using Pearson's correlation test. All statistical analyses in this study were performed with SPSS 19.0 and Origin 2017 software.

\section{Results and Discussion}

Distribution Characteristics of Soil Properties and Potentially Toxic Metals in Soil under Different Land-Use Patterns

The properties of soil samples with three land-use patterns were determined. The results showed that the soil $\mathrm{pH}$ was acidic in PFs (5.15-6.06), ACs (5.83-7.22) and VLs (4.88-7.62). The average SOM contents in PF, $\mathrm{AC}$ and VL were $3.57,1.57$ and $1.02 \mathrm{~g} / \mathrm{kg}$, respectively. Soil physicochemical characteristics and microbial properties will change under different land-use patterns, which will further affect the migration and distribution of potentially toxic metals in soil.

Potentially toxic metal concentrations of soil samples from PFs, ACs and VLs were determined, and variance analysis and multiple comparisons were conducted. The results are shown in Fig. 2.
The concentrations of $\mathrm{Cr}, \mathrm{Cu}, \mathrm{Pb}$ and $\mathrm{Zn}$ at depths of $0-30 \mathrm{~cm}$ were $2.06-127.17,3.09-86.63,2.12-62.44$ and $0.21-32.57 \mathrm{mg} / \mathrm{kg}$, respectively. The concentrations of $\mathrm{Cr}, \mathrm{Pb}$ and $\mathrm{Zn}$ in the three types of land use decreased in the following order: $\mathrm{AC}>\mathrm{PF}>\mathrm{VL}$. The concentration of $\mathrm{Cu}$ decreased in the following order: $\mathrm{AC}>\mathrm{VL}>\mathrm{PF}$. $\mathrm{AC}$ showed significantly $(\mathrm{P}=0.036, \mathrm{P}=0.002)$ higher $\mathrm{Cr}$ and $\mathrm{Zn}$ concentrations than the $\mathrm{PF}$. The concentrations of $\mathrm{Cr}$ and $\mathrm{Zn}$ in $\mathrm{AC}$ were significantly $(\mathrm{P}=0.033$, $\mathrm{P}=0.001, \mathrm{P}=0.022$, respectively) higher than those in VL. However, there were no significant differences in the concentrations of $\mathrm{Cu}$ and $\mathrm{Pb}$ among the three landuse patterns.

Many types of pesticides and fertilizers used in agricultural production contain potentially toxic metals [19-20]. Therefore, they have become an important source of potentially toxic metals in PFs and VLs. However, the concentrations of $\mathrm{Cr}, \mathrm{Cu}, \mathrm{Pb}$ and $\mathrm{Zn}$ in $\mathrm{AC}$ were the highest among the three land-use patterns in this study (Fig. 2). ACs were adjacent to PFs and VLs. Typhoons and rainstorms frequently occur in the study area. Run-off in PFs flows into ACs across ridges, resulting in ACs receiving potentially toxic metals

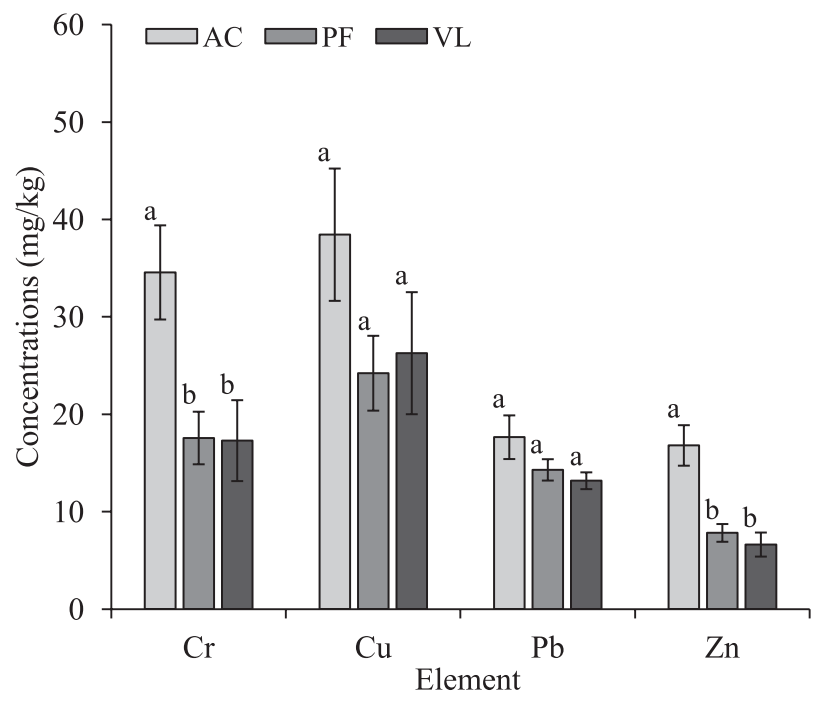

Fig. 2. Distribution characteristics of soil potentially toxic metals concentrations under different land-use types $(n=15, A C ; n=15$, $\mathrm{PF} ; \mathrm{n}=15, \mathrm{VL})$; Different letters represent significant differences $(\mathrm{P}<0.05)$. 
as well [2]. In addition, the ACs are not cultivated or managed. Potentially toxic metals cannot be degraded by soil microorganisms. Therefore, potentially toxic metals are mostly concentrated in topsoil. The soil was relatively loose in the PFs and VLs. Continuous ploughing of PFs and leaching from VLs are conducive to the migration of potentially toxic metals to lower layers. In addition, crops also absorbed potentially toxic metals in the soil [20], resulting in potentially toxic metals in PFs and VLs being lower than those in ACs. This is consistent with the results of Inyang et al. [21], who reported the effect of fallow duration on the concentration of $\mathrm{Cr}$. The concentrations of $\mathrm{Cr}$, $\mathrm{Pb}$ and $\mathrm{Zn}$ in $\mathrm{PFs}$ were slightly higher than those in VLs, while the concentration of $\mathrm{Cu}$ in VLs was higher (Fig. 2). The main reason is that compound fertilizers are commonly used in VLs. The concentrations of $\mathrm{Cu}$ and $\mathrm{Zn}$ in compound fertilizers are relatively high [19], while the concentrations of $\mathrm{Cr}$ and $\mathrm{Pb}$ are relatively low. $\mathrm{Zn}$ shows more potential mobility and bioavailability than $\mathrm{Cu}$ [19] and is more readily migrates downward under the leaching action of rainwater, while $\mathrm{Cu}$ does not readily migrate. Therefore, the $\mathrm{Cu}$ concentration in VLs was higher.

The distribution of potentially toxic metals in the soil profile under different land-use patterns can reflect the trend of migration and transformation in the vertical direction, as shown in Fig. 3. In $\mathrm{AC}$, the concentrations of $\mathrm{Cr}(42.26 \mathrm{mg} / \mathrm{kg}), \mathrm{Cu}(42.30 \mathrm{mg} / \mathrm{kg})$ and $\mathrm{Zn}(19.43 \mathrm{mg} / \mathrm{kg})$ were the highest at a depth of
0-10 $\mathrm{cm}$ and decreased with increasing soil depth, while the concentration of $\mathrm{Pb}(19.99 \mathrm{mg} / \mathrm{kg})$ was the highest at a depth of $10-20 \mathrm{~cm}$. In PF, the concentrations of potentially toxic metals generally increased first and then decreased, mainly concentrated at a depth of 10-20 cm. In VL, the concentrations of potentially toxic metals were mainly concentrated in the surface layer $(0-10 \mathrm{~cm})$. The differences in the vertical distribution of the PF and VL may be related to their different farming methods. Before rice planting, PF soil needs to be turned over and basal fertilizer needs to be applied, which mainly affects the $10-20-\mathrm{cm}$ soil layer. The application of chemical fertilizers and pesticides to VL depends on spraying, which mainly affects the soil surface.

Fractionation Distribution of Potentially Toxic Metals in Soil under Different Land-Use Patterns

The individual chemical fractions of $\mathrm{Cr}, \mathrm{Cu}, \mathrm{Pb}$ and $\mathrm{Zn}$ in the soil from the three land-use patterns were expressed as a percentage of the total metal concentration, as shown in Fig. 4. The proportions of the exchangeable fractions differed slightly. The exchangeable fraction is sensitive to the environment, is easily transferred, transformed and bioabsorbed, and has the strongest toxicity [22].

The proportion of carbonate-bound fractions under the three land-use patterns declined in the following order: $\mathrm{AC}>\mathrm{VL}>\mathrm{PF}$. Driven by economic benefits,

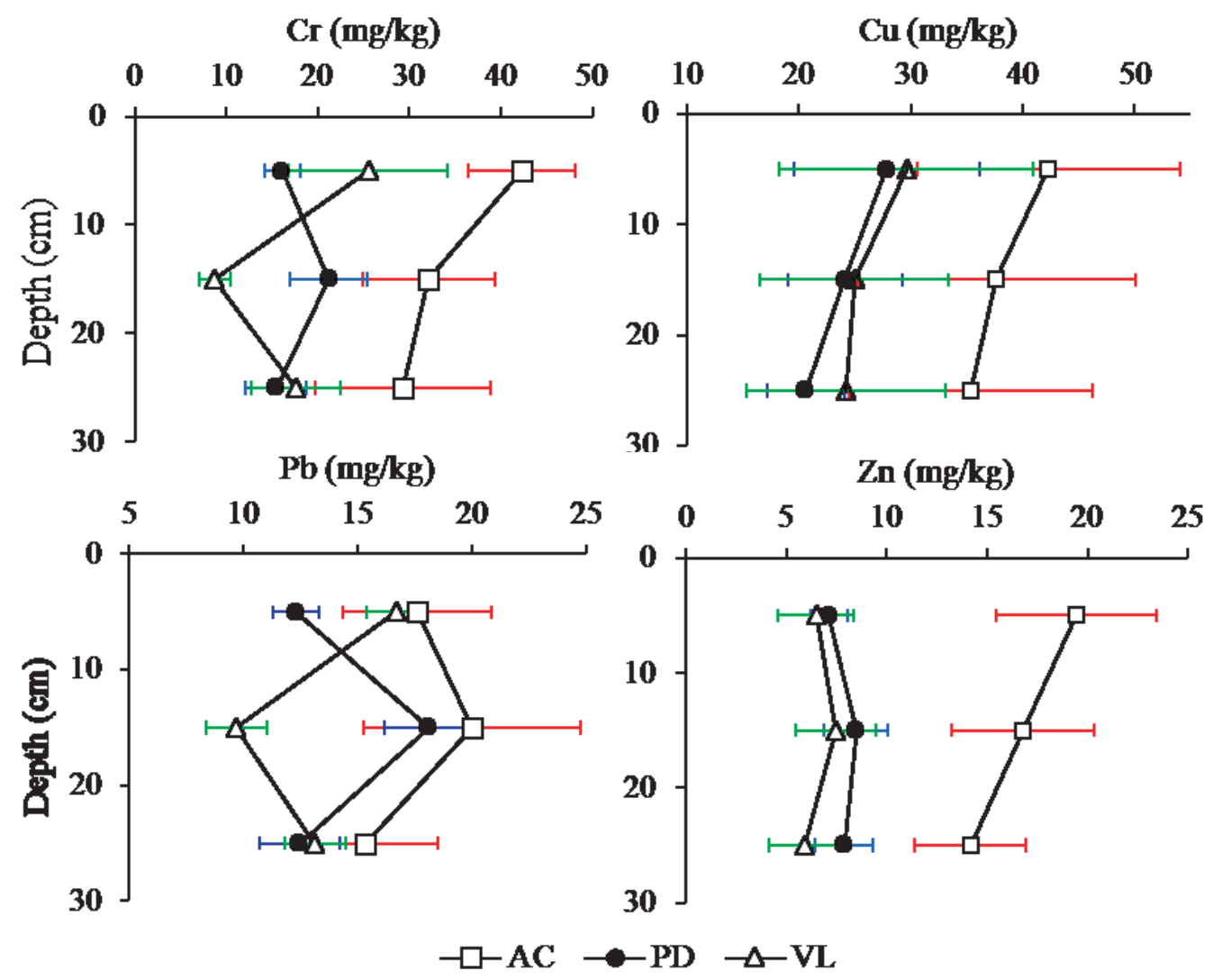

Fig. 3. Distribution patterns of potentially toxic metals in soil profiles under different land-use types $(n=15, A C ; n=15, P F ; n=15, V L)$. 

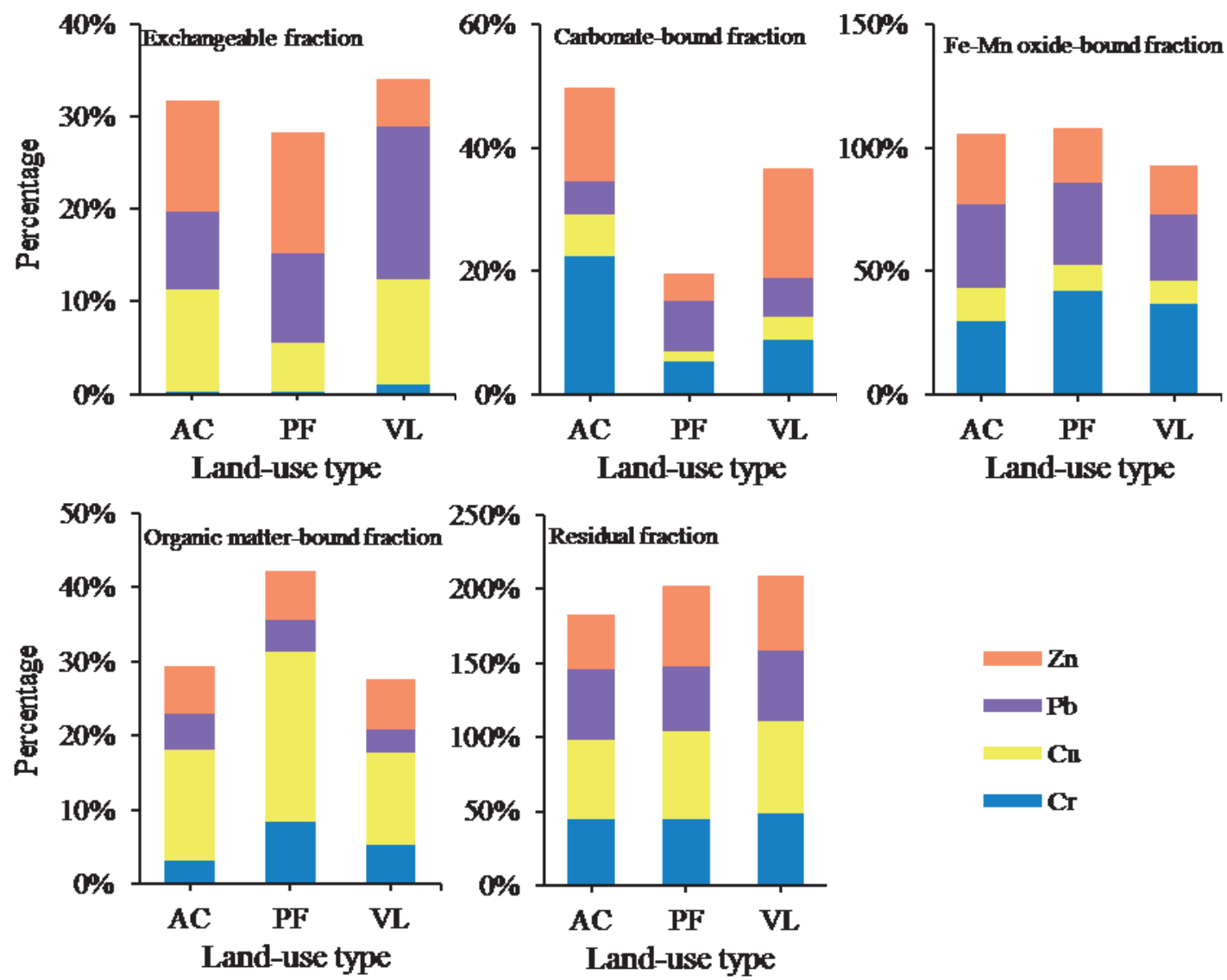

Fig. 4. Fractionation of potentially toxic metals in the surface soils under different land-use types.

farmers applied a large number of pesticides and fertilizers to increase crop yields, which led to the acidification of PF and the decrease of $\mathrm{pH}$ [23-24]. The soil microenvironment is relatively humid, and the base cations are easily leached. As a result, $\mathrm{H}^{+}$accumulates on the soil colloid, and the soil $\mathrm{pH}$ is low [25]. The carbonate-bound fraction is sensitive to soil $\mathrm{pH}$ and is easily released when the $\mathrm{pH}$ decreases [7]. The $\mathrm{PF}$ had the lowest soil $\mathrm{pH}(\mathrm{pH}=5.68)$ and the lowest proportion of the carbonate-bound fraction.

Metals in the Fe-Mn oxide-bound fraction were relatively high in PFs. This fraction is easily released when paddy soil is flooded and hypoxic. The Fe-Mn oxide-bound fraction can cause potential harm and is susceptible to anthropogenic activities.

The proportions of organic-bound fractions in the three land-use patterns were as follows: $\mathrm{PF}>\mathrm{AC}>\mathrm{VL}$. Organic matter-bound fractions of potentially toxic metals exist in a variety of organics. Under aerobic conditions, the organics degrade and release the bound metals, and more SOM in the soil has a greater effect on the absorption of potentially toxic metals [26]. This result is consistent with the order of the SOM concentration: PF $\quad(3.57 \mathrm{~g} / \mathrm{kg})>\mathrm{AC} \quad(1.57 \mathrm{~g} / \mathrm{kg})>\mathrm{VL}$ $(1.02 \mathrm{~g} / \mathrm{kg})$. The SOM in PF was higher than that in AC. Anthropogenic activities such as the application of organic fertilizers supply SOM in PF, which is conducive to the accumulation of SOM $[23,27]$. VL, like PF, is affected by fertilization, but there is no water as a protective layer to inhibit the decomposition of SOM. The decomposition and release of SOM are accelerated by high temperature, sufficient sunshine and strong biological effects in tropical areas [28]. Therefore, the decomposition of SOM content is higher than the supplementary content. The consistent of SOM and organic-bound fraction indicates that SOM can promote the formation of organic-bound fractions.

The residual fractions in VL and PF were higher than those in AC, which is consistent with the conclusion of Yang et al. [29]. They reported that the residual fraction of potentially toxic metals (e.g., Zn and $\mathrm{Cu}$ ) increases after agricultural activities. This finding may suggest that active biological and cultivation behaviors promoted the mobility of metals, resulting in the relative enrichment of residual metals.

\section{Correlation Analysis between the Fraction Concentrations of Potentially Toxic Metals and Selected Soil Properties}

\section{Effects of Soil pH on the Metal Fractions}

The soil in the study area was slightly acidic, with a $\mathrm{pH}$ ranging from 4.88 to 7.62 , with an average value of 6.10. The Pearson correlation analysis results between the fractions of potentially toxic metals and soil $\mathrm{pH}$ 
Table 2. Correlation coefficient matrix between fractionation of potentially toxic metals and $\mathrm{pH}$ in surface soils.

\begin{tabular}{|c|c|c|c|c|c|}
\hline Element & $\begin{array}{c}\text { Exchangeable } \\
\text { fraction }\end{array}$ & $\begin{array}{c}\text { Carbonate-bound } \\
\text { fraction }\end{array}$ & $\begin{array}{c}\text { Fe-Mn oxide-bound } \\
\text { fraction }\end{array}$ & $\begin{array}{c}\text { Organic matter-bound } \\
\text { fraction }\end{array}$ & $\begin{array}{c}\text { Residual } \\
\text { fraction }\end{array}$ \\
\hline $\mathrm{Cr}$ & 0.190 & 0.111 & 0.409 & 0.170 & 0.014 \\
\hline $\mathrm{Cu}$ & -0.028 & 0.030 & 0.082 & 0.201 & -0.149 \\
\hline $\mathrm{Pb}$ & -0.489 & -0.153 & -0.395 & -0.299 & $-0.475^{*}$ \\
\hline $\mathrm{Zn}$ & -0.052 & $0.737^{*}$ & $0.555^{*}$ & 0.136 & -0.253 \\
\hline
\end{tabular}

**, * Significant at $\mathrm{P}<0.01$ and $\mathrm{P}<0.05$, respectively.

are presented in Table 2. The soil $\mathrm{pH}$ showed negative correlations with the exchangeable fractions of $\mathrm{Cu}, \mathrm{Pb}$ and $\mathrm{Zn}$ and positive correlations with the carbonatebound fractions of $\mathrm{Cr}, \mathrm{Cu}$ and $\mathrm{Zn}$, among which there was a significant positive correlation with the carbonatebound fraction of $\mathrm{Zn}(\mathrm{P}<0.05)$. This is because the soil $\mathrm{pH}$ will affect the concentration of soil carbonate. When the $\mathrm{pH}$ decreases, potentially toxic metals will be released due to the dissolution of carbonate. With an increase in soil $\mathrm{pH}$, the concentration of carbonate increases, which readily complexes with potentially toxic metal ions to form carbonate-bound fractions [30], thus reducing the exchangeable fraction of potentially toxic metals in soil. Soil $\mathrm{pH}$ exhibited positive relationships with Fe-Mn oxide-bound fractions of $\mathrm{Cr}, \mathrm{Cu}$ and $\mathrm{Zn}$ and potentially even $\mathrm{Zn}$. The specific adsorption of $\mathrm{Zn}$ on the oxide surface is related to soil $\mathrm{pH}$ [31]. When the $\mathrm{pH}$ increases, most of the adsorbed potentially toxic metal ions become specifically adsorbed; therefore, the $\mathrm{Fe}$ $\mathrm{Mn}$ oxide-bound fractions of $\mathrm{Zn}$ increase. There were positive correlations between soil $\mathrm{pH}$ and the organic matter-bound fractions of $\mathrm{Cr}, \mathrm{Cu}$ and $\mathrm{Zn}$. However, the correlations were not significant. The residual fractions of $\mathrm{Cu}, \mathrm{Pb}$ and $\mathrm{Zn}$ showed positive correlations with $\mathrm{pH}$ and potentially even $\mathrm{Pb}$.

\section{Effects of SOM on the Metal Fractions}

The correlation between different fractions of potentially toxic metals in soil and SOM is shown in Table 3. The organic matter-bound fractions of the four potentially toxic metals showed positive relationships with SOM, among which $\mathrm{Cr}$ and $\mathrm{Cu}$ were significantly correlated at $\mathrm{P}<0.01$ and $\mathrm{Zn}$ at $\mathrm{P}<0.05$, indicating that an increase in SOM can increase the organic-bound states of potentially toxic metals. This may occur because increased SOM enhances the adsorption and complexation ability of potentially toxic metal ions. Therefore, the organic matter-bound fraction concentration of potentially toxic metals increases. In other words, an increase in the SOM concentration reduces the exchangeable sites and metal ions under acidic conditions, transforming them into organic matter-bound fractions [32]. There were both positive and negative correlations between the exchangeable fractions of potentially toxic metals and SOM, indicating that SOM has a dual effect on exchangeable fractions, i.e., it can reduce the concentration of the exchangeable fraction by adsorbing free potentially toxic metals and also plays the role of "ligand" and "migration carrier" by complexing and chelating with potentially toxic metals to improve the solubility of potentially toxic metals. Most of the carbonate-bound fractions exhibited negative relationships with SOM. However, the correlations were not significant. The Fe$\mathrm{Mn}$ oxide-bound fractions of $\mathrm{Cr}, \mathrm{Cu}$ and $\mathrm{Zn}$ showed positive correlations with SOM, among which $\mathrm{Cr}$ was significantly correlated at $\mathrm{P}<0.05$, indicating that an increase in SOM may enhance the complexation between potentially toxic metals and Fe-Mn oxides and increase the concentration of Fe-Mn oxide-bound potentially toxic metals. There was no significant correlation between the residual fractions of the four potentially toxic metals and SOM, which is consistent with the results reported by Honma et al. [33].

Table 3. Correlation coefficient matrix between fractionation of potentially toxic metals and SOM in surface soils.

\begin{tabular}{|c|c|c|c|c|c|}
\hline Element & $\begin{array}{c}\text { Exchangeable } \\
\text { fraction }\end{array}$ & $\begin{array}{c}\text { Carbonate-bound } \\
\text { fraction }\end{array}$ & $\begin{array}{c}\text { Fe-Mn oxide-bound } \\
\text { fraction }\end{array}$ & $\begin{array}{c}\text { Organic matter-bound } \\
\text { fraction }\end{array}$ & $\begin{array}{c}\text { Residual } \mathrm{f} \\
\text { raction }\end{array}$ \\
\hline $\mathrm{Cr}$ & -0.118 & -0.064 & $0.712^{*}$ & $0.925^{* *}$ & 0.279 \\
\hline $\mathrm{Cu}$ & -0.306 & -0.363 & 0.108 & $0.900^{* *}$ & 0.380 \\
\hline $\mathrm{Pb}$ & -0.080 & 0.432 & -0.080 & 0.317 & -0.078 \\
\hline $\mathrm{Zn}$ & $0.673^{* *}$ & -0.293 & 0.196 & $0.540^{*}$ & 0.107 \\
\hline
\end{tabular}

**, * Significant at $\mathrm{P}<0.01$ and $\mathrm{P}<0.05$, respectively. 


\section{Conclusions}

The concentrations of potentially toxic metals in the three land-use patterns were ranked as $\mathrm{AC}>\mathrm{PF}>\mathrm{VL}$. $\mathrm{Cr}, \mathrm{Cu}$ and $\mathrm{Pb}$ in $\mathrm{VL}$ were concentrated in the $0-10-\mathrm{cm}$ soil layer, whereas $\mathrm{Cr}, \mathrm{Pb}$ and $\mathrm{Zn}$ in $\mathrm{PF}$ were concentrated in the $10-20-\mathrm{cm}$ soil layer, mainly due to different tillage and fertilization methods. These results showed that potentially toxic metals in soil are enriched to the tillage layer with the intensification of anthropogenic agricultural activities. Metals showed the highest proportion of the residual fraction in the three land-use types. The highest residual fraction and the relatively low labile fraction showed low mobility and bioavailability. However, the carbonatebound fraction is sensitive to soil $\mathrm{pH}$ and is easily released when $\mathrm{pH}$ decreases, and the $\mathrm{Fe}-\mathrm{Mn}$ oxidebound fraction is easily released when soil is flooded and hypoxic. Because the $\mathrm{pH}$ of $\mathrm{PF}$ is low and crops are planted frequently in tropical areas, more attention should be paid to reducing the risk of carbonatebound fraction and Fe-Mn oxide-bound fraction. In agricultural activities, more suitable cultivation and fertilization methods should be monitored with great concern, which can reduce the hazards of potentially toxic metals.

\section{Acknowledgments}

This study was supported by the Academician Innovation Platform Project (CN) (YSPTZX202024), Hainan Natural Science Foundation Innovation Team (CN) (2017CXTD006) and the Natural Science Foundation of Hainan Province (CN) (419MS049). The authors thank Yaoli Xing for help with sampling.

\section{Conflict of Interest}

No potential conflict of interest was reported by the authors.

\section{References}

1. ORTA-GARCÍA S.T., OCHOA-MARTINEZ A.C., CARRIZALEZ-YÁÑEZ L., VARELA-SILVA J.A., PÉREZ-VÁZQUEZ F.J., PRUNEDA-ÁLVAREZ L.G., TORRES-DOSAL A., GUZMÁN-MAR J.L., PÉREZMALDONADO I.N. Persistent organic pollutants and heavy metal concentrations in soil from the metropolitan area of Monterrey, Nuevo Leon, Mexico. Archives of Environmental Contamination and Toxicology, 70, 452, 2016.

2. ZHAO Z.Y., ZHAO Z.Z., FU B., WU D., WANG J.G., TANG W. Available heavy metal concentrations and their influencing factors in cropland and fallows of different age in tropical area. Polish Journal of Environmental Studies, 30 (2), 1935, 2021. https://doi.org/10.15244/pjoes/126372
3. KELEPERTZIS E., STATHOPOULOU E. Availability of geogenic heavy metals in soils of Thiva town (central Greece). Environmental Monitoring and Assessment, 185, 9603, 2013.

4. LIU C., CUI J., JIANG G.F., CHEN X.F., WANG L., FANG C.M. Soil heavy metal pollution assessment near the largest landfill of China. Soil and Sediment Contamination: An International Journal, 22, 390, 2013.

5. ALSHAHRI F., EL-TAHER A. Assessment of heavy and trace metals in surface soil nearby an oil refinery, Saudi Arabia, using geoaccumulation and pollution indices. Archives of Environmental Contamination and Toxicology, 75, 390, 2018.

6. WEI L.L., WANG K., NOGUERA D.R., JIANG J.Q., OYSERMAN B., ZHAO N.B., ZHAO Q.L., CUI F.Y. Transformation and speciation of typical heavy metals in soil aquifer treatment system during long time recharging with secondary effluent: depth distribution and combination. Chemosphere, 165, 100, 2016.

7. LIU G.N., WANG J., ZHANG E.X., HOU J., LIU X.J. Heavy metal speciation and risk assessment in dry land and paddy soils near mining areas at Southern China. Environmental Science and Pollution Research, 23 (9), 8709, 2016.

8. ZHENG S.A., ZHENG X.Q., CHEN C. Transformation of metal speciation in purple soil as affected by waterlogging. International Journal of Environmental Science and Technology, 10, 351, 2012.

9. HU Y.N., CHENG H.F., TAO S. The challenges and solutions for cadmium-contaminated rice in China: a critical review. Environment International, 92-93, 515, 2016.

10. MA X.L., ZUO H., TIAN M.J., ZHANG L.Y., MENG J., ZHOU X.N., MIN N., CHANG X.Y., LIU Y. Assessment of heavy metals contamination in sediments from three adjacent regions of the Yellow River using metal chemical fractions and multivariate analysis techniques. Chemosphere, 144, 264, 2016.

11. LIU Y., WANG H.F., LI X.T., LI J.C. Heavy Metal Contamination of Agricultural Soils in Taiyuan, China. Pedosphere, 25, 901, 2015.

12. DENG A.M., WANG L., CHEN F., LI Z.G., LIU W.Z., LIU Y. Soil aggregate-associated heavy metals subjected to different types of land use in subtropical China. Global Ecology and Conservation, 16, e00465, 2018.

13. DENG Y., JIANG L.H., XU L.F., HAO X.D., ZHANG S.Y., XU M.L., ZHU P., FU S.D., LIANG Y.L., YIN H.Q., LIU X.D., BAI L.Y., JIANG H.D., LIU H.W. Spatial distribution and risk assessment of heavy metals in contaminated paddy fields- A case study in Xiangtan City, southern China. Ecotoxicology and Environmental Safety, 171, 281, 2019.

14. FU B., LIU Y.Y., ZHAO Z.Z., ZHANG L., WU D., LIU H.F. Dissolved palladium in heavy traffic location runoff: dynamic variation and influencing factors. Urban Water Journal, 15, 880, 2018.

15. TESSIER A., CAMPBELL P.G.C., BISSON M. Sequential extraction procedure for the speciation of particulate trace metals. Analytical Chemistry, 51, 844, 1979.

16. SEO B.H., KIM H.S., KWON S.I., OVENS G., KIM K.R. Heavy metal accumulation and mobility in a soil profile depend on the organic waste type applied. Journal of Soils and Sediments, 19, 822, 2019.

17. YU Y.C., YANG J.Y., ZENG S.C., WU D.M., JACOBS D.F., SLOAN J.L. Soil pH, organic matter, and nutrient 
content change with the continuous cropping of Cunninghamia lanceolata plantations in South China. Journal of Soils and Sediments, 17, 2230, 2015.

18. FARSHADIRAD A., HOSSEINPUR A., MOTAGHIAN H. Distribution and availability of copper in aggregate size fractions of some calcareous soils. Journal of Soils Sediments, 19, 1866, 2019.

19. PENG H., CHEN Y.L., WENG L.P., MA J., MA Y.L., LI Y.T., ISLAM M.S. Comparisons of heavy metal input inventory in agricultural soils in North and South China: A review. Science of Total Environment, 660, 776, 2019.

20. ZHANG J.R., LI H.Z., ZHOU Y.Z., DOU L., CAI L.M., MO L.P., YOU J. Bioavailability and soil-to-crop transfer of heavy metals in farmland soils: A case study in the Pearl River Delta, South China. Environmental Pollution, 235, 710, 2018.

21. INYANG E.P., OKETAYO O.O., OBIAJUNWA E.I. Proton induced X-ray emission analysis of soils with various length of fallow: The effect on soil total elemental composition. Soil \& Tillage Research, 124, 178, 2012.

22. SAUVE S., MCBRIDE M., HENDERSHOT W. Soil solution speciation of lead(II): Effects of organic matter and $\mathrm{pH}$. Soil Science Society of America Journal, 62, 618, 1998.

23. CAI Z.J., WANG B.R., XU M.G., ZHANG H.M., HE X.H., ZHANG L., GAO S.D. Intensified soil acidification from chemical $\mathrm{N}$ fertilization and prevention by manure in an 18-year field experiment in the red soil of southern China. Journal of Soils and Sediments, 15, 260, 2015.

24. ZHU Q.C., LIU X.J., HAO T.X., ZENG M.F., SHEN J.B., ZHANG F.S., DE VRIES W. Modeling soil acidification in typical Chinese cropping systems. Science of the Total Environment, 613-614, 1339, 2018.

25. ZHANG H., ZHAO X.M., OUYANG Z.C., GUO X., KUANG L.H., YE Y.C. Effects of different farmland use types on soil nutrients in Jiangxi Province. Research of Soil and Water Conservation, 25(6), 53, 2018.
26. LI Y.Q., CHEN L., QIU Y.L., ZHAO J.F., LI J.Z. Speciation of heavy metals in soil from Shanghai Chemical Industry Park. Ecology and Environment, 13, 154, 2004.

27. ZHAO Z.Z., ZHAO Z.Y., FU B., WANG J.G., TANG W. Characteristics of soil organic carbon fractions under different land use patterns in a tropical area. Journal of Soils and Sediments, 21, 689, 2020.

28. AALTONEN H., PALVIAINEN M., ZHOU X., KÖSTER E., BERNINGER F., PUMPANEN J., KÖSTER K. Temperature sensitivity of soil organic matter decomposition after forest fire in Canadian permafrost region. Journal of Environmental Management, 241, 637, 2019.

29. YANG S.L., ZHOU D.Q., YU H.Y., WEI R., PAN B. Distribution and speciation of metals $(\mathrm{Cu}, \mathrm{Zn}, \mathrm{Cd}$, and $\mathrm{Pb})$ in agricultural and non-agricultural soils near a stream upriver from the Pearl River, China. Environmental Pollution, 177, 64, 2013.

30. QIAO D., QI X., PANG H., FAN T., DU Z., HU C., FAN X., HUANG Z. The effect of $\mathrm{pH}$ level on existing form of $\mathrm{Pb}^{2+}$. Journal of Soil and Water Conservation, 24 (6), 173, 2010.

31. SILBER A., BAR-YOSEF B., SURYANO S., LEVKOVITCH I. Zinc adsorption by perlite: Effects of $\mathrm{pH}$, ionic strength, temperature, and pre-use as growth substrate. Geoderma, 170, 159, 2012.

32. LU A.X., ZHANG S.Z., SHAN X.Q. Time effect on the fractionation of heavy metals in soils. Geoderma, 125, 225, 2005.

33. HONMA T., OHBA H., MAKINO T., OHYAMA T. Relationship between cadmium fractions obtained by sequential extraction of soil and the soil properties in contaminated and uncontaminated paddy soils. Journal of Chemistry, 2015, ID714680, 2015. 